\title{
Becoming American
}

The Forced Experience of the Peruvian Japanese

AUTHOR: Courtenay Smith

EDITED BY: Rudi Smith, Esti Azizi, and Marisa Coulton

As a result of the Japanese attack on Pearl Harbor, December 7, 1941, President Franklin D. Roosevelt authorized the Secretary of War "to prescribe military areas...from which any or all persons may be excluded." Executive Order 9066, authorized February 19, 1942, gave the Secretary of War Henry L. Stimson and specified Military Commanders, the power to designate specific military zones in which persons deemed a danger to the country may be excluded. Additionally, Stimson directed and provided these persons with "transportation, food, shelter, and other accommodations as may be necessary." ${ }^{1}$ He also designated the United States west coast a military zone, including Washington, Oregon and California, in which the army would exile 120,000 persons of Japanese birth or ancestry by the end of World War II. ${ }^{2}$ As of December 1941, the west coast was home to 90,000 of the 130,000 Japanese Americans living on the United States mainland. ${ }^{3}$ As an act of military necessity, the order was unanimously passed by Congress, and welcomed by most Americans, as it eliminated Japanese presence in the economy. ${ }^{4}$ Anti-Japanese sentiments stemmed from the false belief that successful Japanese farmers and cheap Japanese labour created economic competition and undermined white workers' jobs. ${ }^{5}$ By June 1942, all Japanese nationals within the military zone were expelled. ${ }^{6}$ They were first brought to assembly centres scattered along the coast. From there they were transported to one of ten "relocation centres" or internment camps administered by the War Relocation Authority. ${ }^{7}$ In addition to interning
120,000 Japanese Americans due to their perceived danger, the United States expanded their operation beyond the United States into Central and South America.

The year prior to Pearl Harbor, the Federal Bureau of Investigation (FBI) began observing suspected dangerous persons, or "alien enemies," on the United States west coast. ${ }^{8}$ They urged South American countries with axis power nationals or sympathizers to do the same. ${ }^{9}$ In June 1940, the $\mathrm{FBI}$ authorized non-military intelligence to operate across the Western Hemisphere, including South America. The following year, United States embassies furthered their involvement, and began working as liaison officers with local police in South America, gathering information of suspected dangerous persons. ${ }^{10}$ At this time, as the United States began interning their own Japanese nationals, and encouraged South American countries to follow their lead. At a Conference of Foreign Ministers of the American Republics held in Rio de Janeiro in January 1942, the Emergency Committee, an inter-American state body, adopted the United States' policy to detain those of axis nationalities, known as Resolution XX. ${ }^{11}$ Sixteen South American countries, including Peru, Panama, El Salvador and Bolivia, detained 85,000 axis nationals. Furthermore, on invitation, twelve of these countries deported a portion of their axis nationals to the United States. ${ }^{12}$ The initial plan was to repatriate them to their country of origin, whether Japan, Germany or Italy, through the United 
States. ${ }^{13}$ Specifically, the American government planned to use these detainees in exchange for American prisoners of war. ${ }^{14}$ Between July 1942 and September 1943, 2,400 Japanese South Americans were used in exchanges with Japan by the U.S. State Department. ${ }^{15}$ However, 2,118 were shipped to the United States, and interned alongside Japanese Americans, deported without any charges or official hearings. ${ }^{16}$ 1,024 Japanese men were deported as "dangerous" persons, and 1,094 of their wives and children voluntarily followed. ${ }^{17} 80$ per cent of the Japanese nationals deported from South America were from Peru. ${ }^{18}$

Similar to the United States, the deportation of the Peruvian Japanese was welcomed partially for national security, but mainly for the elimination of economic competition. The men deported were not randomly selected individuals, but business owners compiled on a "blacklist," such as Atsumi Ozawa's father, a successful store owner in Huancayo, Peru. ${ }^{19}$ This paper focuses on the Peruvian Japanese who, once brought to the United States, were interned at Crystal City Internment Camp, alongside Japanese Americans. In 1946, approximately 301 Peruvian Japanese remained in the United States, seemingly just as unfamiliar with American culture as the day they arrived. ${ }^{20}$ Even though they were detained alongside Japanese Americans, the Peruvian Japanese experienced isolation from true American society. In Crystal City, the Peruvian Japanese were not forced and had no to reason to adapt to American culture. It was only once they could not return to Peru, and refused to move to Japan, that they realized they would remain in United States, a country that did not welcome them, and Americanize. This paper argues that the process of Americanization among the Peruvian Japanese at Crystal City Internment Camp did not truly begin until 1946, when they moved away from the camp and became active members in American society.

This paper uses the interviews of six detained Japanese nationals who were children of various ages at their time of detainment at Crystal
City Internment Camp made available through Densho's digital archives project. Japanese Americans Joe Yasutake, Mako Nakagawa, and Saturo Ichikawa were all Nisei, American-born with Japanese-born parents, whose fathers were identified as "dangerous" enemy aliens. All three of their families were separated from their fathers for two years of internment and were reunited at Crystal City. ${ }^{21}$ Art Shibayama, Atsumi Ozawa, and Elsa Kudo were all Peruvian-born Nisei, whose families followed their fathers aboard ships to the United States, and were, too, reunited at Crystal City. Additionally, Elsa Kudo's father Seiichi Higashide's memoir, Adios to Tears, is used to supplement where childhood memories are lacking, as well as to demonstrate an adult perspective. This essay relies heavily on interviews of detainees who were children in those years, because Higashide's memoir is a rare retelling of an adult detainee's experience. Many tried to forget their years spent interned and did not share their stories. ${ }^{22}$ Although there are many introductory sources on Japanese Americans' experience in United States internment camps during World War II, the same material is lacking for the Peruvian Japanese. Harvey C. Gardiner's Pawns in a Triangle of Hate is the leading text on the subject of Peruvian Japanese internees, and is used throughout this essay as the main background source on their experience.

Crystal City Internment Camp, located in Southern Texas, was the only "family camp" in the United States. ${ }^{23}$ As such, it solved the "special problem" of married detainees with dependent families. ${ }^{24}$ Crystal City was the largest internment camp operated by the Immigration and Naturalization Service (INS). ${ }^{25}$ At the end of the war, it held a population of approximately 3,300 internees. ${ }^{26}$ In addition to the predominate population of Japanese nationals, Crystal City contained a small population of German nationals, both from South America and the United States. ${ }^{27}$ The camp operated like a small city - children attended school, detainees bought food and clothes at the market, continued worshipping at the church or temple, participated in extracurricular activities, 
and buried their dead in the local cemetery. ${ }^{28}$ Japanese adults were not forced to work, but many accepted jobs within the camp to occupy their time, and earned a small income of ten cents per hour. ${ }^{29}$ Employment included jobs such as farming, as well as morning milk and ice delivery. ${ }^{30}$ Art Shibayama attended school and worked with the postmaster, picking up mail in the morning, and delivering it at lunch and after school. ${ }^{31}$ Crystal City, seemingly, was not intentionally organized to separate the different cultural groups, but housing, school and extracurricular activities forced noticeable differences between the Peruvian and American Japanese. As a result, opportunities to interact between groups were overlooked, and the Peruvian Japanese were not often influenced by American culture.

As the Peruvian Japanese were among the last to arrive at Crystal City, and because they arrived together, all were assigned living quarters in the same area. ${ }^{32}$ They were not purposely separated from the Japanese Americans but were simply given what accommodations remained. All of Crystal City's residences contained a sink, stove, cooking utensils, and dishes so that the detainees could cook for themselves. ${ }^{33}$ This allowed families to eat together, which was specifically remembered among the Japanese American internees Joe Yasutake and Mako Nakagawa, who had been separated from their fathers before reuniting at Crystal City. ${ }^{34}$ The ability to cook their own food and eat in their own residence was a unique characteristic of Crystal City, as other American internment camps required the detainees to eat in a mess hall together. ${ }^{35}$ Therefore, eating as a family and cooking their own meals reinforced these separate communities between the Peruvian and American Japanese. As a result of living among other Peruvian Japanese and cooking their own food, Peruvian Japanese identity remained separate from Japanese Americans.

Everyday life in Crystal City was similar for Peruvian Japanese and Japanese American children, but experienced separately due to linguistic and cultural barriers. Japanese American and Peruvian children continued their education and attended school at Crystal City. The camp contained three separate school systems, Japanese, English and German, as Seiichi Higashide explained, and the detainees referred to the schools by the language they were taught in out of convenience. ${ }^{36}$ However, the label of "Japanese" and "English" enforced the idea that the children who attended each school were different from each other. The Peruvian Japanese attended the Japanese school, while Japanese Americans typically went to the English school. Once again, the Peruvian and American children were not separated intentionally; it was simply due to the language they spoke that determined which school they attended. Japanese Americans attended English-speaking schools prior to being interned, therefore it was logical that they continued to do so. ${ }^{37}$ However, the Peruvian Japanese attended the Japanese school, because they had attended bilingual, Japanese- and Spanish-speaking schools in Peru. ${ }^{38}$

Similar to the case concerning separate communities, the Peruvian and American Japanese children remained separated since they attended separate schools. As a result, Peruvian Japanese children did not interact with many Japanese Americans, and, in attending Japanesespeaking schools, were not forced to learn English. Additionally, since their parents planned on returning to Peru after the war, there was no reason to learn. ${ }^{39}$ Therefore, the Peruvian Japanese continued to primarily speak Spanish or Japanese, whereas the Japanese Americans spoke English. The language barrier occurred naturally between the children. The Americans who attended the Japanese school were mainly from Hawaii, although some from mainland America also attended. ${ }^{40}$ Furthermore, some Japanese Americans, such as Nakagawa, attended a Japanese language school that was held on Saturday. Though Japanese Americans and Peruvians could communicate with each other in Japanese, and did so on occasion, overall the two groups tended to not socialize with each other. This meant that the Peruvian children maintained 
their own cultural customs and would not have been heavily influenced by Japanese American culture.

The children participated in a variety of activities, including swimming at the communitymade pool, ${ }^{4}$ baseball, judo lessons, and going to movies. ${ }^{42}$ Even though both Americans and Peruvians participated in these activities, they remained separated by language. The two groups were able to communicate with each other in Japanese, but preferred to spend time with those that spoke their primary language - English for the Americans, and Spanish for the Peruvians. However, the Peruvian and Hawaiian Japanese were better friends since they both knew more Japanese than the mainland Americans, and had a more Japanese style. $^{43}$ In essence, the American Japanese saw the Peruvians as more Japanese. Joe Yasutake states that, unlike Americans, they embodied "the old country," carrying on with traditional Japanese customs like bowing. ${ }^{44}$ Furthermore, Thomas Connell argued that Peruvian parents reinforced Japanese customs, such as Japanese language, and sports, so that upon their return to Peru the children would not be Americanized. ${ }^{45}$ However, the Densho oral histories give no evidence to this. Peruvian children went to the Japanese school because they knew Japanese. Furthermore, it was the Japanese American interviewees, Yasutake and Nakagawa, who mentioned attending camp activities that originated from Japan, like judo and sumo lessons. ${ }^{46}$ In addition, Japanese Americans, like Nakagawa, attended Japanese language school in the camp. ${ }^{47}$ This demonstrates that there was no distinction of Peruvians being more Japanese than the Americans. Instead, the Americans were inclined to perceive the Peruvians as being more Japanese. All children, whether Peruvian or American, enjoyed swimming, and playing baseball, although in their separate groups.

Interestingly, the Peruvian Japanese did not note the same cultural differences, instead believing the lack of friendships with Americans was due to the language barrier..$^{48}$ Atsumi Ozawa says she had more Japanese Hawaiian than mainland friends, because they spoke more Japanese. ${ }^{49}$ There were no conflicts between the two groups, but they primarily remained in their separate groups. They played on their own baseball teams, and went to movies playing in their own language. ${ }^{50}$ Peruvian and American children's lives in Crystal City paralleled one another, and with the exception of occasional socializing, remained separate.

Similar to Connell's argument, C. Harvey Gardiner stated that many Peruvian Japanese parents were:

looking forward to repatriation to Japan- they wanted their children to emphasize their study of Japanese in order to minimize any penalty accompanying their transfer to Japanese schools. This emphasis on their Japanese heritage, reinforced by the production of Japanese-language plays, speaking contest, movies, and more, simultaneously repudiated the prospect of Americanization. ${ }^{51}$

However, this argument cannot be applied as a general statement to all detained Peruvian Japanese. As Gardiner states, Japanese-language plays, movies, and school did aid in opposing Americanization of the Peruvians. However, the Densho oral histories give no evidence that these devices were used for the specific purpose of doing so. Like the school divide, Japanese plays and movies were attended by the Peruvian Japanese, because they spoke only Japanese and Spanish. Yet, Japanese American Mako Nakagawa's parents did want to return to Japan. Nakagawa explains that her parents "were very loyal to Japan. They thought the emperor -- they thought Japan was going to win the war... They always planned to return to Japan...I remember my mom saying she [would] die for the emperor." ${ }^{\text {52 }}$ Additionally, Nakagawa and her siblings attended weekday Japanese school after their regular English school, as well as all day on Saturdays. ${ }^{53}$ Nakagawa's experience demonstrates that some Japanese Americans wanted to return to Japan, however he story is not representative of the entire Japanese 
population of Crystal City.

Other Japanese American families, such as Yasutake and Ichikawa, had no thoughts of returning to Japan after the war was over. ${ }^{54}$ Additionally, most Peruvian Japanese families did not want to return to Japan. Shibayama's father even attempted to dissuade others from returning, he was so passionate about the subject. ${ }^{55}$ Furthermore, Shibayama demonstrates Gardiner's argument was a perception shared amongst Japanese Americans. Joe Yasutake believed that only the Peruvian Japanese discussed returning to Japan, which was not surprising as he believed them to be more "old country" than himself and other Japanese Americans. ${ }^{56}$ Yet, as was shown in the case of Nakagawa's family, Japanese Americans were also considering returning. Therefore, Connell and Gardiner's arguments that Peruvian Japanese emphasized Japanese heritage for the purpose of returning to Peru or Japan were true for some, but did not represent the majority of the Peruvian Japanese in the camp.

There is an argument to be made for Americanization beginning towards the end of the Peruvian Japanese detention at Crystal City. Elsa Kudo recalls that she began to eat American food like hot dogs and peanut butter in the camp. ${ }^{57}$ Furthermore, as the war ended and the camp slowly shut down, so too did the school system. The Japanese-speaking teachers began to leave, and so the Japanese speaking school closed. In its place, two Japanese American Nisei began to teach English to the Peruvian Japanese. These were not mandatory school lessons, but some attended as there was not much else to occupy their time. Additionally, it was unknown to many families where they would live once the camp closed, so if they remained in the United States at least the children could begin to learn English. ${ }^{58}$ However, these children would become nowhere near fluent in English until years after they left the camp. ${ }^{59}$ Although change in diet and language are signs of Americanization, the acts explained here are insignificant when compared to the shifts that would occur later in their lives.

Of the approximate 2,118 Peruvian Japanese that were forcibly detained to the United States, ${ }^{60}$ around 1,700 departed for Japan with the belief that returning to Peru or remaining in the United States were not options. ${ }^{61}$ In 1946, approximately 301 Peruvian Japanese detainees were left, 23 of whom were born in Crystal City. ${ }^{62}$ As the United States prepared for their departure, they were left in a state of confusion of where to go,. They did not want to move to Japan, a place many of them had never been, and Peru refused to allow the return of any previously deported Japanese nationals. ${ }^{63}$

A month before the bombing of Hiroshima and Nagasaki in July 1945, the United States government began preparations to deport those of Japanese heritage whom were "deemed by the Attorney General to be dangerous to the public peace and safety of the United States." ${ }^{4}$ This desire was further specified in September through Presidential Proclamation 2662 where alien enemies were to be deported if they were living:

within the continental limits of the United States (1) who were sent here from other American republics for restraint and repatriation...(2) who are within the territory of the United States without admission under the immigration laws are, if their continued residence in the Western Hemisphere is deemed by the Secretary of States prejudicial to the future security or welfare of the Americas. ${ }^{65}$

Upon review by the State Department's Chief of Alien Control, April 6 1946, the approximate 301 Peruvian Japanese remaining in the United States were found not to be dangerous and were no longer considered alien enemies under Proclamation 2662. ${ }^{66}$ However, the Peruvian Japanese were still under the jurisdiction of the INS, and were subject to hearings relating to their illegal immigrant status. ${ }^{67}$ Documents, passports, any proof of Peruvian citizenship had been taken away from them upon 
arrival in the United States. Additionally, no records had been created to document their entrance into the country. ${ }^{68}$ The INS deemed the Peruvian Japanese illegal immigrants. None possessed an immigration visa, and due to their Japanese ancestry, they were ineligible to apply for American citizenship. Thus, the INS ordered them to be deported within thirty days. ${ }^{69}$ Fortunately, the Peruvian Japanese were able to contact attorney Wayne M. Collins, who was already working on a case with Japanese American clients at Crystal City. Collins filed habeas corpus on behalf of the Peruvian Japanese, delaying their deportation..$^{70} \mathrm{He}$ also pushed the government to allow the Peruvian Japanese to work at Seabrook Farms, Inc., while the case was processed. ${ }^{71}$ So the Peruvian Japanese began the fight to remain in the United States, a country they knew little about, even through their experience at Crystal City.

Of the group left at Crystal City, 209 went on parole to New Jersey to work at Seabrook Farms in $1946 .^{72}$ Seabrook was a food freezing and packing company that sponsored the Peruvian Japanese. ${ }^{73}$ The process of Americanization among the Peruvian Japanese began at Seabrook, but would not fully occur until after the Peruvians moved out. Some families, such as Shibayama's, were still hoping to return to Peru. ${ }^{75}$ In preparation for such an event, employment at Seabrook was seen as an opportunity to make more money than they had been making at Crystal City. ${ }^{76}$ Therefore, the Peruvian Japanese did not enter Seabrook expecting to remain in the United States, but saw it as an intermediary stage before returning to Peru, and so would not have tried to assimilate to American culture. Furthermore, Seabrook was not a true representation of American society, as its population was composed mainly of Japanese nationals. During the war, Seabrook's staff was composed of German and Japanese Americans who had not been detained by the military zone of the west coast. However, as Higashide explains, when the war ended, the Germans and most of the Japanese Americans returned home and the Peruvian Japanese were hired to fill the positions. ${ }^{77}$ The facility had a similar demographic to Crystal
City, and operated like a "relaxed internment camp." ${ }^{78}$ Seabrook contained a library, gymnasium, canteen, lunch room, ${ }^{79}$ as well as living quarters partially enclosed in a high chain link fence, resembling Crystal City. ${ }^{80}$

Seabrook is where Higashide first experienced differences between himself as a Peruvian Japanese, and other American workers. His first job at the plant was in the freezing section for lima beans, where he scooped buckets of beans as they came down through an opening and poured them into trolley containers. ${ }^{81}$ Higashide was one of few men stationed along this line, and the beans would not pour out equally between them, so one may not be able to handle the volume pouring towards them. In such a situation, instead of being wasteful and allowing beans to fall on the floor, Higashide rushed over to another's station to help them. After doing this several times in his first week a senior worker explained to Higashide that this act was not very American of him. "I don't think you understand the American system," Higashide recalled the worker telling him, "[w]hatever happens, do not interfere with the job of another person. In this country, this is what is understood as 'consideration."'82 The worker further explained that if the company management saw Higashide helping another worker they would increase the rate of beans, increasing everyone's work output without any increase in wages..$^{83}$ Higashide believed what his co-worker said to be true, however, he felt the situation to be "un-Japanese," and felt uneasy working in the "American system" the worker had described. ${ }^{84}$ Life at Seabrook was the Peruvian Japanese's first true introduction to American society.

Furthermore, the Peruvian Japanese had only seen the United States on their journey to Crystal City, and going to Seabrook was their first time truly interacting with American society, rather than the small portion that the Japanese American internees represented. Additionally, it demonstrates how little the Peruvian Japanese had Americanized at Crystal City. They had seen no reason to 
learn English, and as a result, were unable to communicate with English-speaking Americans. On the way to Seabrook, the train stopped for a few hours in St. Louis, Missouri. Higashide took advantage of the stopover, deciding to take his children to the zoological gardens. However, due to his lack of English he was unable to communicate with the cab drivers as he identified their desired destination saying, "zoh, please" believing this to mean "zoological gardens" in English. Only once they found a Hispanic cab driver and were able to communicate in Spanish did the Higashide family reach their destination. ${ }^{85}$

Additionally, Bridgetown, the closest town to Seabrook, was the first American town Higashide and his wife got to know and experience. On their first trip there to buy clothing, they were confronted with what they felt to be a "cold and impersonal" experience. ${ }^{86}$ Unlike in Peru, where Higashide had owned and operated his own store, transactions in America did not involve friendly conversation between the employee and customer, and items purchased were not carefully wrapped in paper. ${ }^{87}$ Additionally, it was also the first time they experienced a self-service store, where the customer was trusted to handle the items for sale and bring them to the cashier. A system Higashide was certain would have never worked in Peru. ${ }^{88}$ Seabrook introduced the Peruvian Japanese to what American society was truly like. Although it was not as isolated as Crystal City, Seabrook was still a small area that the Peruvian Japanese lived in among other Japanese nationals. They did not truly integrate into American society until they left Seabrook Farms for a 'real' American city.

After spending a few years at Seabrook, most Peruvian Japanese began to leave, accepting that they would not be returning to Peru, ${ }^{89}$ and in search of a better life for their children. ${ }^{90}$ Many Peruvian Japanese went to Chicago, because they knew of another person or family that could help them gain employment. ${ }^{91}$ Although there was a population of Peruvian Japanese in Chicago, they did not all live in the same area as they had in Crystal City and Seabrook Farms - this was the first time that they were exposed to American society without other Peruvians by their side. ${ }^{92}$ Some children, like Shibayama, continued to learn English at Seabrook through participation in the Seabrook baseball team. ${ }^{93}$ However, it was the reality of others upon arrival in Chicago, especially adults, that they had yet to become fluent in English. Atsumi Ozawa arrived in 1948 at the age of twenty and attended an English language school for adults every morning from nine to twelve. ${ }^{94}$ English was necessary to find employment in Chicago, unlike at Seabrook and Crystal City where Peruvians freely spoke in Spanish or Japanese. In Chicago, a lack of English meant unstable employment and living in poverty for Higashide who spoke almost no English upon arrival in the city. ${ }^{95}$ Furthermore, Higashide believed that his children adopted the American work ethic, "study hard, work hard," through their family's impoverished years in Chicago. ${ }^{96}$ The Peruvian Nisei's began to attend American universities. ${ }^{97}$ In doing so they began to mainly speak English, progressing as members of the American society. ${ }^{98}$ Only once the Peruvian Japanese began to operate in a real American city living amongst non-Japanese Americans, were they forced to learn English to gain employment.

Although the Peruvian Japanese were active members of American society by the 1950s, they legally gained the right to remain in the United States in 1954. Public law 751 amended the Refugee Relief Act of 1953, allowing them to apply to the Attorney General to change their immigration status from illegal to legal immigrants. After this, they received a proper immigration visa and permanent residency. As legal immigrants the Peruvian Japanese could apply for naturalization under public law 414, passed in 1952.

The Peruvian Japanese discussed in this essay did not choose to live in the United States, but were forcibly imported to and detained there. The select group remaining after internment were not Americanized by their experience at Crystal City Internment Camp. They stayed separate 
from the Japanese Americans through segregated housing, specific language schools, and the primary language spoken daily. These were not instruments purposefully used to keep the two groups apart, but arose naturally through the dynamics of the camp. Therefore, the Peruvians were not forced to Americanize themselves, as a result of the lack of interaction between the Peruvian and American Japanese. Unable to return to Peru, and unwilling to move to Japan, the remaining Japanese at Crystal City moved, on parole, to Seabrook Farms. This was their first real interaction with American society. Seiichi Higashide's memories of shopping in Bridgetown and the "American system" demonstrate that Crystal City had not operated like true American society did, leaving the paroled internees to again learn a new way of life. However, Seabrook was also not a true representation of American life. The population of the packing company was composed mainly of Japanese nationals, and so the Peruvian Japanese continued to abstain from learning English, as there was no pressing reason to. This reason soon presented itself in the move to Chicago in 1948. In Chicago, the Peruvian Japanese were no longer surrounded by Japanese nationals, and had to learn English to communicate with those around them and find employment. Furthermore, the Peruvian Japanese Nisei led the Americanization in Chicago, as they quickly became fluent in English, attended university and went on to become functioning members of the American society. Despite being surrounded by Japanese Americans at Crystal City, the Peruvian Japanese only Americanized after they left the camp and were forced to assimilate to become functioning members of American society. The Peruvian Japanese, nor the American government, expected the group to permanently remain in the United States. So it was not until both groups were forced with the reality that they would be staying, that the Peruvian Japanese had a reason and began to adapt to American society.

\section{ENDNOTES:}

1. Franklin D. Roosevelt, 'Executive Order 9066Authorizing the Secretary of War to Prescribe
Military Areas,' The American Presidency Project, (February 19, 1942), http://www.presidency.ucsb. edu/ws/?pid=61698.

2. Roger Daniels, Prisoners without Trial: Japanese Americans in World War II (New York, 1993), p.19.

3. Daniels, Prisoners without Trial, p.19.

4. Ibid.,

5. Alice Yang Murray, 'Introduction: The Internment of Japanese Americans,' in Alice Yan Murray (ed.), What Did the Internment of Japanese Americans Mean? (New York, 2000), p.6.

6. Daniels, Prisoners without Trial, p.54.

7. Daniels, Prisoners without Trial, p.21.

8. Murray, 'Introduction,' p.3.

9. Edward N. Barnhart, 'Japanese Internees from Peru,' Pacific Historical Review 31 (1962), p.170. 10. Barnhart, 'Japanese Internees from Peru,' p.170.

11. Michi Weglyn, 'Why did U.S. Officials Intern People of Japanese Ancestry from Central and South America?: Hostages,' in Alice Yan Murray (ed.), What Did the Internment of Japanese

Americans Mean? (New York, 2000), p.89.

12. Barnhart, 'Japanese Internees from Peru,' p.172.

13. C. Harvey Gardiner, Pawns in a Triangle of Hate: The Peruvian Japanese and the United States (Seattle, 1981), p.17.

14. Art Shibayama, interview by Alice Ito, Densho Digital Archive (Seattle, Washington, 2003), segment (seg.) 8.

15. Murray, 'Introduction,' p.80.

16. Gardiner, Pawns in a Triangle of Hate, p.27; Seiichi Higashide, Adios to Tears: The Memoirs of a Japanese-Peruvian Internee in U.S. Concentration Camps (Seattle, 2000), p.177.

17. Weglyn, 'Why Did U.S. Officials Intern,' p.92.

18. Barnhart, 'Japanese Internees from Peru,' p.172.

19. Atsumi Ozawa, interview by Tom Ikeda, Densho Digital Archive (Skokie, Illinois), seg.7.

20. Gardiner, Pawns in a Triangle of Hate, p.139.

21. Joe Yasutake, interview by Alice Ito, Densho Digital Archive (Seattle, Washington, 2002), seg.1; Mako Nakagawa, interview by Lori Hoshino, Densho Digital Archive (Seattle, Washington, 1998) seg.12; Saturo Ichikawa, interview by Tom Ikeda, Densho 
Digital Archive (Seattle, Washington, 2009), seg. 15. 22. Murray, 'Introduction,' 19.

23. Weglyn, 'Why Did U.S. Officials Intern,' p.92.

24. United States Immigration and Naturalization

Service, 'Alien Enemy Detention Facility, Crystal City, Texas,' narrated by Bern Berard, (1945; Washington, D.C.: Department of Justice), video.

25. Gardiner, Pawns in a Triangle of Hate, p.59.

26. Ibid., p.61.

27. Gardiner, Pawns in a Triangle of Hate, p.60.

28. Higashide, Adios to Tears, p.165.

29. Gardiner, Pawns in a Triangle of Hate, 60.

30. US INS, 'Alien Enemy Detention Facility.'

31. Art Shibayama, seg.10.

32. Satoru Ichikawa, seg.7; Art Shibayama, seg.15.

33. Gardiner, Pawns in a Triangle of Hate, p.60.

34. Mako Nakagawa, seg.13; Joe Yastuke, seg.2.

35. Murray, 'Introduction,' p.12.

36. Higashide, Adios to Tears, p.168.

37. Mako Nakagawa, seg.13.

38. Art Shibayama, seg.11; Atsumi Ozawa, seg.3.

39. Gardiner, Pawns in a Triangle of Hate, p.119.

40. Atsumi Ozawa, seg.13.

41. Elsa Kudo, interview by Kelli Nakamura, Densho

Digital Archive (Honolulu, Hawaii, 2012), seg.12; Art

Shibayama, seg.13.

42. Atsumi Ozawa, seg.13.

43. Atsumi Ozawa, seg.13.

44. Joe Yasutake, seg.3.

45. Thomas Connell III, 'The Internment of LatinAmerican Japanese in the United States during World War II: The Peruvian Japanese Experience,' (PhD dissertation, Florida State University, 1995), p.181.

46. Joe Yasutake, seg.3; Mako Nakagawa, seg.13.

47. Mako Nakagawa, seg.13.

48. Art Shibayama, seg.15.

49. Atsumi Ozawa, seg.13.

50. Mako Nakagawa, seg.18.

51. Gardiner, Pawns in a Triangle of Hate, p.103.

52. Mako Nakagawa, seg.15.

53. Ibid., seg.13.

54. Joe Yasutake, seg.4; Ichikawa, seg.20.

55. Art Shibayama, seg.13.

56. Yasutake, seg.3.

57. Elsa Kudo, seg.12.

58. Art Shibayama, seg.14.

59. Atsumi Ozawa, seg.15.
60. Higashide, Adios to Tears, p.177.

61. Barnhart, "Japanese Internees from Peru," p.174.

62. Gardiner, Pawns in a Triangle of Hate, p.139.

63. Atsumi Ozawa, seg.15.

64. Harry S. Truman, 'Proclamation 2655-Removal of Alien Enemies,' The American Presidency Project, (July 14, 1945), http://www.presidency.ucsb.edu/ ws/?pid $=87034$.

65. Harry S. Truman, 'Proclamation 2662-Removal of Alien Enemies,' The American Presidency Project, (September 8, 1945), http://www.presidency.ucsb. edu/ws/?pid=87040.

66. Barnhart, "Japanese Internees from Peru," p.175.

67. Ibid.,

68. Gardiner, Pawns in a Triangle of Hate, p. 139.

69. Barnhart, "Japanese Internees from Peru," p.175.

70. Ibid.,

71. Gardiner, Pawns in a Triangle of Hate, p.14.

72. Ibid., p.155.

73. Art Shibayama, seg.14.

74. Higashide, Adios to Tears, p.179.

75. Art Shibayama, seg.14.

76. Gardiner, Pawns in a Triangle of Hate, p.150.

77. Higashide, Adios to Tears, p.181.

78. George G. Olshausen, "Experiment at Seabrook Farms," Far Eastern Survey 16 (1947), p. 201.

79. Olshausen, "Experiment at Seabrook Farms," p. 201.

80. Higashide, Adios to Tears, p.182.

81. Ibid., p.185.

82. Ibid., p.186.

83. Ibid.,

84. Ibid.,

85. Ibid., p.180.

86. Ibid., p.190.

87. Ibid.,

88. Higashide, Adios to Tears, p.189.

89. Art Shibayama, seg.19.

90. Higashide, Adios to Tears, p.193.

91. Ibid., p.194.

92. Ibid., p.199.

93. Art Shibayama, seg.20.

94. Atsumi Ozawa, seg.15

95. Higashide, Adios to Tears, p.198.

96. Ibid., p.214. 
97. Ibid., p.124.

98. Ibid., p.219.

\section{BIBLIOGRAPHY:}

\section{Primary Sources}

Higashide, Seiichi, Adios to Tears: The Memoirs of a Japanese-Peruvian Internee in U.S. Concentration Camps (Seattle, 2000).

Ichikawa, Saturo, interview by Tom Ikeda, Densho Digital Archive (Seattle, Washington, 2009).

Kudo, Elsa, interview by Kelli Nakamura, Densho Digital Archive (Honolulu, Hawaii, 2012).

Nakagawa, Mako, interview by Lori Hoshino, Densho Digital Archive (Seattle, Washington, 1998).

Olshausen, George G., 'Experiment at Seabrook Farms,' Far Eastern Survey 16 (1947), pp. 200-201.

Ozawa, Atsumi, interview by Tom Ikeda, Densho Digital Archive (Skokie, Illinois).

Roosevelt, Franklin D., 'Executive Order 9066Authorizing the Secretary of War to Prescribe Military Areas,' The American Presidency Project, (February 19, 1942), http://www. presidency.ucsb.edu/ws/?pid=61698.

Shibayama, Art, interview by Alice Ito, Densho Digital Archive (Seattle, Washington, 2003).

Truman, Harry S., 'Proclamation 2655-Removal of Alien Enemies,' The American Presidency Project, (July 14, 1945), http://www. presidency.ucsb.edu/ws/?pid=87034.

Truman, Harry S., 'Proclamation 2662-Removal of Alien Enemies,' The American Presidency Project, (September 8, 1945), http://www. presidency.ucsb.edu/ws/?pid=87040.

United States Immigration and Naturalization Service, 'Alien Enemy Detention Facility, Crystal City, Texas,' narrated by
Bern Berard, (1945; Washington, D.C.: Department of Justice), video, https:// archive.org/details/AlienEnemy

DetentionFacility.

Yasutake, Joe, interview by Alice Ito, Densho Digital Archive (Seattle, Washington, 2002).

\section{$\underline{\text { Secondary Sources }}$}

Barnhart, Edward N., 'Japanese Internees from Peru,' Pacific Historical Review 31 (1962), p.169-178.

Connell, Thomas III, 'The Internment of LatinAmerican Japanese in the United States during World War II: The Peruvian Japanese Experience,' (PhD dissertation, Florida State University, 1995).

Daniels, Rogers, Prisoners without Trial: Japanese Americans in World War II (New York, 1993).

Gardiner, Harvey C., Pawns in a Triangle of Hate: The Peruvian Japanese and the United States (Seattle, 1981).

Matsumoto, Valerie J., 'What was the Impact of Internment on Japanese American Families and Communities: Amache,' in Alice Yang Murray (ed.), What Did the Internment of Japanese Americans Mean? (New York, 2000), pp.121-150.

Murray, Alice Yang, 'Introduction: The Internment of Japanese Americans,' in Alice Yang Murray (ed.), What Did the Internment of Japanese Americans Mean? (New York, 2000), pp.126.

Weglyn, Michi, 'Why did U.S. Officials Intern People of Japanese Ancestry from Central and South America?: Hostages,' in Alice Yang Murray (ed.), What Did the Internment of Japanese Americans Mean? (New York, 2000), pp.79-100. 